\title{
World-system Studies of the Environment
}

\author{
by \\ Tim Bartley \\ Department of Sociology \\ University of Arizona \\ Tucson, AZ 85721 \\ bartley@u.arizona.edu \\ and \\ Albert Bergesen \\ Department of Sociology \\ University of Arizona \\ Tucson, AZ 85721 \\ albert@u.arizona.edu
}

Cite: Bartley, Tim, and Albert Bergesen. (1997). "World-system Studies of the

Environment." Journal of World-Systems Research $<$ http://jwsr.ucr.edul $>3: 369$ - 380.

ABSTRACT: The world-system idea has been used to explain a great deal about national institutional life, from rates of economic growth to changing patterns of schooling. One of the newer areas of interest is the environment. In the following review we examine scholarship that deals with environmental problems from a distinctly world systemic perspective.

C 1997 Tim Bartley \& Albert Bergesen.

[Page 369]

Journal of World-Systems Research

\section{Environmental Degradation}

\subsection{Deforestation}

Several quantitative studies have shown that the semiperiphery is the site of the most intense deforestation (Burns, Kick, Murray, and Murray 1994; Kick, Burns, Davis, Murray, and Murray 1996). First, there is a long history of exploitation of peripheral and semiperipheral forests by core countries, and as Chew (1996) notes there is an historical association between colonialism and deforestation in Southeast Asia. Spain and Portugal, Holland, Britain, and the U.S. have all exploited Asian forests during their periods of dominance in the world-system. When a country is rapidly developing and rising to a hegemonic status its level of timber consumption rises. Japan for instance has recently 
experienced a dramatic increase in wood and timber consumption, with as much as $50 \%$ of $\log$ imports and $98 \%$ of plywood imports coming from southeast Asia.

Second, while population growth leads to deforestation in all sectors of the world-system, its effects are exacerbated in the semiperiphery, as population growth necessitates the production of more lumber and thus leads to deforestation (Kick et al, 1996). Yet Burns et al. (1994) and Kick et al. (1996) find that for semiperipheral countries, rural population growth is a better predictor of deforestation than is total population growth, arguing that urban concentration in the semiperiphery causes landless people to migrate out of the city into forested areas--what is called the process of rural encroachment. Since these migrants possess little knowledge of agricultural practices they end up contributing to deforestation. Much more deforestation is attributable to 'slash and burn' activity by landless migrant poor people, conversion of forests to pasture land, and over-harvesting of fuel wood, than it is to commercial logging (Burns et al. 1994:225). Although the process of rural encroachment occurs within a society, the urbanization that leads to outmigration is a consequence of rapid uneven development of semiperipheral countries in the world-system.

In addition, semiperipheral countries deforest more than others because of their position of potential upward mobility in the world-system, which leads them to place more weight on industrialization than on environmental protection. 1 Smith (1994) notes that Newly Industrializing Countries (NICs) tend to have lax environmental regulations. Because of their potential for economic development, semiperipheral countries are more eager to reap the economic benefits of forest exploitation than are developed countries. Further, semiperipheral countries have a greater technological capability to deforest than do peripheral countries (Burns et al. 1994; Kick et al. 1996).

Such semiperipheral states have historically allowed or even encouraged deforestation in attempting to economically develop. Chew (1996) provides an example in his analysis of post-colonial southeast Asia. He argues that attempts to build export-led economies and Western-style states have secured the cooperation of political elites and transnational corporations in exploiting forests. Nazmi (1991), though not espousing a world-system perspective, offers a similar example for the case of Brazil, noting that government incentives for cattle ranching have increased deforestation; badly defined property rights have encouraged small-scale, destructive agriculture; and an emphasis on pig iron production has necessitated deforestation in order to allow the planting of eucalyptus trees used in iron production. If Southeast Asian and Brazilian examples of state facilitated deforestation are generalizable to other semiperipheral countries, then the study of deforestation illustrates a more general process. States are important units of analysis, but since they act in the context of the world-system, they cannot be treated as self-contained entities.

[Page 370]

Journal of World-Systems Research 
States are tied to the world-system through international trade, and trade in forest products is another factor related to deforestation. One would expect that major exporters of forest products would experience high levels of deforestation. Conversely, one would expect that when a country imports forest products, it should not need to deplete its own forests. Yet Kick et al. (1996) find that these expectations hold up only for core countries, not for semiperipheral ones. Interestingly, in semiperipheral countries both the export and import of forest products leads to deforestation. This is because core countries are able to export forest products without high rates of deforestation because they often utilize reforestation practices. (While reforestation results in old-growth forests being replaced by young trees, these are nonetheless counted as forests). When core countries import timber, they need to exploit fewer of their own forest resources, but when semiperipheral countries import timber it often indicates building infrastructure, which damages forested lands regardless of the source of the forest products used. In sum, whether core countries import or export forest products, they experience less deforestation. Semiperipheral countries, on the other hand, are in a lose-lose situation; whether they export or import forest products, the result is deforestation $\underline{2}$.

\subsection{Global Warming and the Curvilinear Hypothesis}

A second environmental problem that has been studied from a world-system perspective is global warming. The two Greenhouse gases--carbon dioxide and methane--are emitted through different processes. Carbon dioxide is produced directly through fossil-fuel use and indirectly through deforestation. Methane production occurs through wet rice agriculture, livestock, uncontrolled coal mine emissions, and petroleum and natural gas leakages (Burns, Davis, and Kick 1997).

In their study of emissions of these two gases, Burns et al. (1997) find that carbon dioxide is produced mostly in highly developed and methane in less developed countries. They create the category "semicore" in order to distinguish between stronger (semicore) and weaker (semiperipheral) states that have previously been lumped together as semiperipheral. This strength can be seen primarily in terms of global network ties, but typically is reflected domestically as well (Burns et al. 1997:10). The semicore includes the weak, non-core countries of Eastern and Western Europe, as well as China, Israel, Australia, and Brazil. The semiperiphery thus consists of the remaining countries that have normally been called semiperipheral.

The social dynamics by which Greenhouse gases are differentially emitted vary with countries' world-system position (Burns et al. 1997). Core countries produce the most carbon dioxide, followed by the semicore, semiperiphery, and periphery. The high level of energy consumption in the core, which results from a high standard of living, explains the primacy of the core in producing carbon dioxide and the decreasing levels of such production for each less affluent sector of the world-system. The semicore produces the most methane, followed by the core, semiperiphery, and periphery. Burns et al. (1997) suggest that the movement of commercial cattle ranching from core to semicore countries and the association of agriculture with methane production explain the high levels of this Greenhouse gas produced there. 
[Page 371]

Joumal of World-Systems Research

These findings suggest that the relation between world-system position and Greenhouse gas emission does not mirror the relation between world-system position and economic development. Economically, there is a clear hierarchy from core to periphery, but the core is not the exclusive emitter of Greenhouse gases, nor is it able to transfer all production of these gases to less developed areas. World-system dynamics (e.g. concentration of wealth and power in the core) are likely to manifest themselves in a number of ways, which may include environmental outcomes that are most severe somewhere other than the core (Burns et al. 1997:32). Economic relations structure the world-system, but they cannot be simplistically projected onto areas such as environmental degradation. For instance, while the relationship between economic and socio-political development is essentially linear, the relationship between economic development and toxic emissions seems to be curvilinear.

Interestingly, it is only in the last twenty years that the relationship between development and emissions has become increasingly curvilinear in the shape of an inverted U (Roberts and Grimes 1997; Grimes and Roberts 1995; Grimes, Roberts, and Manale 1994). That is, currently, emission of carbon dioxide per unit GDP increases with increases in GDP per capita up to around $\$ 8,000-10,000$ GDP per capita, at which point the relationship begins to curve downward (Roberts and Grimes 1997; Grimes and Roberts 1995; Dietz and Rosa 1997; Hettige, Lucas, and Wheeler 1992; Lucas, Wheeler, and Hettige 1992). In other words emissions are most intense in moderately developed (semiperipheral) countries and less intense in less developed (peripheral) and highly developed (core) countries. 3 Roberts and Grimes (1997) thus liken this pattern to the observed Kuznets curvilinear relation between income inequality and national development which indicates that as a country develops, its inequality first increases, then begins to decrease. Yet the environmental Kuznets curve is not exactly analogous to the original Kuznets curve because the environmental curve is found by looking at countries with different levels of development, not at particular countries' processes of development. The emergence of an inverted U-curve is the result not of individual countries passing through stages of development, but of a relatively small number of wealthy ones becoming more efficient since 1970 while the rest of the world worsens (Roberts and Grimes 1997:196). It is also doubtful that most countries will develop to the point of decreasing carbon dioxide emissions (Roberts and Grimes 1997; Dietz and Rosa 1997). While more affluent countries still contribute the most to overall carbon dioxide emissions, what the environmental Kuznets curve findings suggests is that they pollute less intensely, or exhibit more societal efficiency than less developed countries (Grimes and Roberts 1995). Bergesen, Parisi, and Downey (1996) identify two possible explanations for the decreased intensity of emissions in core countries: (1) developed countries possess newer and cleaner technologies than do core countries. (2) they have moved from manufacturing toward service-oriented economies. Lucas et al. (1992) and Hettige et al. (1992) support the latter possibility by showing that, when pollution intensity is measured 
per unit of industrial output rather than unit of GDP, the inverted U-shaped relation nearly disappears. Intensity of manufacturing output rises steadily with income, at most tapering off somewhat at very high incomes (Hettige et al. 1992:479). In other words, new technologies do not seem to be cleaning up industrial production.

[Page 372]

Journal of World-Systems Research

\section{Natural Resources and Development}

Environmental degradation is not just caused by development dynamics, but such degradation can become the context in which future development must occur. Bunker $(1984,1985)$ shows the impact of both ecological degradation and natural resources on political and economic development/underdevelopment. He argues that Brazil's underdevelopment, environmental degradation, and state bureaucratic procedures are tightly linked and each has impacted the other. Once Brazil was incorporated into the world-system in the 16th century, processes of natural resource extraction decimated the indigenous population and their ecologically sound technologies and huge numbers of slaves died on expeditions for sugar and spices that only got longer as local resources were depleted. In addition European trade in animal oils reduced the indigenous population's food supply and disturbed fragile ecosystems. As the natural resource base declined, so did the Amazonian economy. This depletion of the rural population meant that during the Brazilian rubber boom of the mid to late 19th century, capitalists' costs were increased by the necessity of recruiting workers from urban areas. These high costs eventually led to the downfall of the Brazilian economy, as rubber came to be produced more efficiently on English plantations in Asia. In the wake of the rubber boom, the Brazilian environment was further depleted and degraded as those laborers remaining from the rubber boom over-farmed fragile land and traded in animal skins which further disturbed the ecosystem. Environmental conditions are seen as both consequence and cause of Amazonian underdevelopment:

The depopulation, environmental disruption, and demographic and economic dislocations brought about by the previous modes of extraction created the conditions for both largescale capitalist enterprise and government economic planners to treat the Amazon as an empty frontier from which profits could be rapidly and wastefully extracted with little regard for, or sustained economic participation by, existing socioeconomic or environmental systems (Bunker 1985:77).

Bunker's theoretical notions are also closely tied to processes in nature, as his ecological model of uneven development $(1985: 49)$ is inspired by the second law of thermodynamics. This principle of entropy states that while there can be no net loss of energy, the transformation of energy from one form to another will result in it becoming increasingly disorganized, or degraded (Erlich, Erlich, and Holdren 1993).

Underdevelopment in economies based on natural resource extraction is a function of the 
core's ability to obtain useful forms of energy from the periphery and semiperiphery, degrading the latter. If energy and matter necessarily flow from extractive to productive economies, it follows that social and economic processes will be intensified and accelerated in the productive economy and will become more diffuse and eventually decelerate in the extractive economy (Bunker 1985:47). In addition, Bunker (1985) argues, economies based on the extraction of natural resources necessitate a theory of development based on the mode of extraction rather than one based on the mode of production since forms of energy cannot be reproduced and sustained in the same sense as labor and capital.

[Page 373]

Journal of World-Systems Research

Access to natural resources in the rise to hegemonic status is explored by Bunker and Ciccantell (1997), who argue that ascendancy requires the implementation of new strategies for entering raw material markets and accommodating to the natural environment. These strategies include imperialist conquest of resource-rich peripheries, technological innovations that effectively change established relations between economy and environment, and the shifting of capital costs and financial risks to peripheries (Bunker and Ciccantell 1997:10). Technological innovations in Holland, Britain, and the U.S. served to increase the scale at which natural resource extraction and transport occurred. Japan's recent ascent has also hinged largely on its ability to convince semiperipheral countries, who occupy a weak bargaining position, to assume the costs of tailoring transport infrastructures to Japanese specifications as well as the costs of environmental protection (Bunker and Ciccantell 1997, 1995; Bunker 1994).

The rise of countries from periphery to semiperiphery has also been facilitated by natural resource strategies. There has been a raw materials route to the semiperiphery that has existed since World War II. Venezuela, Brazil, Iran, Mexico, Saudi Arabia, India, and others have diversified their production away from dependence on exporting a single raw material to gaining investment from Trans-National Corporations to develop domestic industries that process several resources (Ciccantell 1994). Of course, such a rise to the semiperiphery requires, in addition to sufficient political and economic causes, that large deposits of diverse raw materials exist in these countries.

\section{Environmental Constraints and Social Change}

Chase-Dunn and Hall $(1996,1997)$ operate on a larger and more abstract level, namely the changes in world-systems in the 12,000 years since the establishment of sedentary societies. They propose an ecological and evolutionary theory of the formation and expansion of world-systems that recognizes the ways in which environmental constraints direct the formation of world-systems and more energy-intensive economic practices. They propose an iterative model of long term social change that identifies recurring processes linking population pressure, environmental degradation, hierarchy formation, 
and economic intensification, arguing that social change occurs as a consequence of populations expanding beyond their ecological base. 4

The iterative model accounts for the formation of hierarchical world-systems as follows: Population growth leads to ecological degradation, which limits the natural resources available to the population at the existing level of effort. When such a condition of population pressure exists, people tend to emigrate to new regions. If emigration is inhibited by geographical features or other populations --environmental or social circumscription--people may develop new technologies of production to sust ain themselves in the face of scarcity or they may come into conflict over the existing resources. If conflict takes the form of war, enough people may be killed that population pressure is reduced. Alternatively, conflict may lead to the formation of hierarchical polities, which foster technological intensification. Technological intensification contributes directly to further population growth and environmental degradation. These processes occur repeatedly, and thus there is an increase in both the scale of worldsystems and the scale of environmental degradation.

[Page 374]

Journal of World-Systems Research

Chase-Dunn and Hall's model applies even to complex societies characterized by capitalism and large markets. When societies become more complex, several new paths of change become possible. Institutional structures allow population pressure to lead directly to new hierarchies and technologies, bypassing the basic path of the model through circumscription and conflict. Unlike other theories of long term change, here the development of a capitalist world-system does not radically alter the logic of the theory. In periods of system expansion, the superstructure of geopolitical accumulation overrides the underlying demographic and resource scarcity const raints of the iteration model (Chase-Dunn and Hall 1997:112). Yet in periods of contraction, the superstructural dynamics fade and these constraints re-emerge.

Even the contemporary global world-system is subject to demographic and ecological constraints, and Chase-Dunn and Hall suggest that such constraints could turn periods of contraction into crises and allow for a transformation to a socialist world-system. The crucial point here, from both a theoretical and environmental standpoint, is that current environmental factors do not lose their importance just because local constraints are increasingly replaced by global constraints in the contemporary world-system.

Another approach is taken by O'Connor (1994) who theorizes the issue of an ecological crisis for capitalism from a perspective different from Chase-Dunn and Hall. He brings the environment into a Marxist analysis of global capitalism, arguing that environmental degradation produced through capitalist enterprise constitutes a "second contradiction " of capitalism. Marx's first contradiction asserted that capitalism's exploitation and alienation of the proletariat would lead to the overthrow of the system. O'Connor's eco-Marxism 
now shifts the focus to capitalism's exploitation of the natural environment. As capital degrades the environment, it increases the costs of future expansion and thus leads to its own demise. O'Connor says:

Cost-side crises originate in two ways. The first is when individual capitals defend or restore profits by strategies that degrade or fail to maintain over time the material conditions of their own production, for example, by neglecting work conditions (hence raising the health bill), degrading soils (hence lowering the productivity of land), or turning their backs on decaying urban infrastructures (hence increasing congestion costs). The second is when social movements demand that capital better provides for the maintenance and restoration for these conditions of life (1994:162).

The demise of social systems throughout time has also been a result of ecological degradation, according to Chew (1997) who argues that the Bronze Age civilizations of Mesopotamia and Harappa represent core centers that were significantly interconnected economically. Through these economic ties, en vironmental degradation both inside and outside each core center contributed to that center's economic crises.

[Page 375]

Journal of World-Systems Research

Therefore, an ecological crisis in Mesopotamia might mean the lowering of agricultural output or production, and consequently a reduction in the overall supply of goods to other parts of the system. Concomitantly, such reductions would impact on other regions such as Dilmun and Harappan in terms of a diminished demand for their materials and goods (Chew 1997:19).

\section{Regimes, Movements, and World Polities}

Environmental degradation poses practical problems for people and states today. Political action directed toward environmental regulation is obviously related to the increasing scale and intensity of degradation in the last century. Yet increased degradation does not seem to fully explain the rise of international environmental regimes or social movements. Frank (1994) argues that increasing participation in environmental treaties is due not simply to increased degradation, but to a reconstitution of the concept of nature into an ecosystem paradigm. Through a content analysis of environmental treaties, he shows that international discourse has gone from viewing nature as a realm of chaos and savagery, and away from conceptions of nature as a cornucopia of resources to recognizing planet-wide interdependencies (Frank, 1994:2). In addition, through an event-history analysis of the number of treaties, he shows that the increasing coherence of a world polity has led to more treaties, while the consolidation and routinization of governmental mechanisms for dealing with environmental problems tends to decrease the number of international treaties. In other words, as the politics of the world-system have become more global, international environmental treaties have become more prevalent. 
Frank (1995) also argues that it is social rather than economic ties to the world-system that determine the level of a state's participation in international environmental regulation. He finds that social ties to world society are related more consistently and strongly to the ratification of environmental treaties than are economic development and political structure. As an ecosystem cultural frame has gained strength global associations, states and organizations have used world-system social networks to pressure others to participate, and environmental regulation has become more closely associated with state legitimacy.

While Frank $(1994,1995)$ focuses on world-system cultural constructions and network ties, Roberts (1996) explains environmental treaty participation strictly on the basis of political and economic factors. He finds that indicators of world-system position and internal political climate are both determinants of environmental treaty participation. The likelihood of participation decreases with national wealth, indebtedness, dependence on few trading partners, and the existence of a repressive state government. Several explanations underlie these findings. For one, peripheral and semiperipheral countries are simply less able to participate in treaties. Indebtedness also discourages a country from risking its ability to produce raw materials by participating in treaties and countries that are dependent on few trading partners are more economically vulnerable and therefore less likely to alienate their trading partners by signing a treaty. Repressive regimes are also not sensitive to popular demands for regulation and therefore not likely to sign environmental treaties. While the finding that repressive states are unlikely to participate argues for the importance of democracy, Roberts finds that world-system position is consistently the best predictor of participation.

[Page 376]

Joumal of World-Systems Research

Although peripheral and semiperipheral countries seem unlikely to participate in environmental treaties, they may spawn environmental social movements. Smith (1994) has made preliminary arguments for connections between levels of development/worldsystem position and movement emergence. He points out that Newly Industrializing Countries are in a contradictory situation: their upward mobility leads to environmental degradation yet creates conditions of urbanization and education that are favorable toward the emergence of social movements acting in opposition to polluting industries. Sinith provides only introductory remarks on environmental antisystemic movements, but it is possible to hypothesize that the combination of severe environmental degradation and urbanization in semiperipheral countries would make them the most fertile ground for the growth of environmental movements. Schaeffer (1997) makes a similar hypothesis arguing that the environmental movement finally began to grow in peripheral countries in the 1980 's because of democratization and increased perceptions of resource scarcity caused by the debt crisis and austerity programs. During the 1970 's on the other hand, environmental movements did not take hold in the periphery though they were prevalent in the U.S. and most other core countries, as many in the periphery associated 
environmentalism with the U.S. government, its imperialist foreign policy and population control efforts. In addition, the same wave of inflation that helped create the perception of resource scarcity in core countries was increasing incomes in energy and natural resource-based economies.

\section{Conclusion}

World-System studies of the environment primarily answer questions about environmental degradation, natural resources, long-term social change, and forms of environmental activism. They also provide insight into more general world-system dynamics: upward mobility in the semiperiphery, evolutionary growth and transformation of world-systems, and state action in a hierarchical world-system. Incorporating the environment into world-system research allows us to recognize a material base that is ecological as well as economic and to consider the environment a possible independent variable.

\section{References}

Bergesen, Albert, Laura Parisi, and Liam Downey. 1996. "Development and Pollution: Is the Relationship Curvilinear?" Presented at the annual meeting of the International Studies Association, April, San Diego, CA.

Bunker, Stephen G. 1984. Modes of Extraction, Unequal Exchange, and the Progressive Underdevelopment of an Extreme Periphery: The Brazilian Amazon. American Journal of Sociology 89:1017-64.

[Page 377]

Journal of World-Systems Research

-----. 1985. Underdeveloping the Amazon: Extraction, Unequal Exchange, and the Failure of the Modern State. Urbana: University of Illinois Press.

----. 1994. Flimsy Joint Ventures in Fragile Environments. Pp.261-96 in States, Firms, and Raw Materials: The World Economy and Ecology of Aluminum, edited by B. Barham, S. Bunker, and D. O'Hearn. Madison: University of Wisconsin Press.

Bunker, Stephen and Paul S. Ciccantell. 1995. Restructuring Space, Time and Competitive Advantage in the Capitalist World-Economy: Japan and Raw Materials Transport after World War II. Pp. 109-129 in A New World Order? Global Transformation in the Late Twentieth Century, edited by D. A. Smith and J. Borocz. Westport, CT: Greenwood. 
-----. 1997. Economic Ascent and the Global Environment: World Systems Theory and the New Historical Materialism. Presented at the Political Economy of the world-system XXI Conference, April, Santa Cruz, CA.

Burns, Thomas J., Byron L. Davis, and Edward L. Kick. 1997. Position in the WorldSystem and National Emissions of Greenhouse Gases. Revision of paper presented at the National Third-World Studies Conference, October, Omaha, NB.

Burns, Thomas J., Edward L. Kick, David A. Murray, and Dixie A. Murray. 1994. Demography, Development and Deforestation in a World-System Perspective. International Journal of Comparative Sociology 35:221-239.

Carneiro, Robert L. 1970. A Theory of the Origin of the State. Science 169 (August):733738.

Chase-Dunn, Christopher and Thomas D. Hall. 1996. Ecological Degradation and the Evolution of World-Systems. Presented at the annual meeting of the American Sociological Association, August, New York, NY.

-----. 1997. Rise and Demise: Comparing World-Systems. Boulder, CO: Westview.

Chew, Sing C. 1996. Wood, Environmental Imperatives and Developmental Strategies: Challenges for Southeast Asia. Pp. 206-226 in Asia-Who Pays for Growth? Women, Environment, and Popular Movements, edited by J. Lele and W. Tettey. Brookfield, VT: Darmouth.

-----. 1997. Ecological Relations and the Decline of Kingdoms and Civilizations 2500BC to 1700BC: Some Considerations on Mesopotamia and Harappa. Prese nted at the Political Economy of the World System XXI Conference, April, Santa Cruz, CA.

Ciccantell, Paul S. 1994. The Raw Materials Route to the Semiperiphery: Raw Materials, State Development Policies and Mobility in the Capitalist World-System. Presented at the annual meeting of the American Sociological Association, August, Los Angeles, CA.

Cohen, Mark. 1977. The Food Crisis in Prehistory. New Haven: Yale University Press.

Dietz, Thomas, and Eugene A. Rosa. 1997. Effects of Population and Affluence on CO2 Emissions. Proceedings of the National Academy of Sciences of the USA 94(Jan.):175-79.

Ehrlich, Paul R., Anne H. Ehrlich, and John P. Holdren. 1993. Availability, Entropy, and the Laws of Thermodynamics. Pp.69-73 in Valuing the Earth: Economics, Ecology, Ethics, edited by H. Daly and K. Townsend. Cambridge, MA: The MIT Press.

Frank, David John. 1994. Science, Nature, and the Globalization of the Environment, 1870-1990. Presented at the annual meeting of the American Sociological Association, August, Los Angeles, CA. 
[Page 378]

Joumal of World-Systems Research

1995. The Nation-State and the Natural Environment, 1900-1995. Presented at the annual meeting of the American Sociological Association, August, Washington, DC.

Grimes, Peter E. and J. Timmons Roberts. 1995. Carbon Dioxide Emissions Efficiency and Economic Development. Presented at the annual meeting of the American Sociological Association, August, Washington, DC.

Grimes, Peter E., J. Timmons Roberts, and Jodie L. Manale. 1994. Social Roots of Environmental Damage: A world-systems Analysis of Global Warming and Deforestation. Revision of paper presented at the annual meeting of the American Sociological Association, August, Miami Beach, FL.

Harris, Marvin. 1977. Cannibals and Kings: The Origins of Cultures. New York: Random House.

-----. 1979. Cultural Materialism: The Struggle for a Science of Culture. New York: Random House.

Hettige, Hemamala, Robert E.B. Lucas, and David Wheeler. 1992. The Toxic Intensity of Industrial Production: Global Patterns, Trends, and Trade Policy.? American Economics Review 82:478-81.

Kick, Edward L., Thomas J. Burns, Byron Davis, David A. Murray, and Dixie A. Murray. 1996. Impacts of Domestic Population Dyamics and Foreign Wood Trade on Deforestation: A World-System Perspective. Journal of Developing Societies 12:68-87.

Leonard, H. Jeffrey. 1988. Pollution and the Struggle for the World Product: Multinational Corporations, Environment, and International Comparative Advantage . Cambridge: Cambridge University Press.

Low, Patrick, and Alexander Yeats. 1992. Do Dirty Industries Migrate? Pp. 89-104 in International Trade and the Environment, edited by P. Low. World Bank Discussion Papers, no. 159. Washington, DC: International Bank for Reconstruction and Development/World Bank.

Lucas, Robert E.B., David Wheeler, and Hemamala Hettige. 1992. Economic Development, Environmental Regulation and the International Migration of Toxic Industrial Pollution: 1960-88. Pp.67-86 in International Trade and the Environment, edited by P. Low. World Bank Discussion Papers, no. 159. Washington, DC: International Bank for Reconstruction and Development/World Bank. 
Nazmi, Nader. 1991. Deforestation and Ecnomic Growth in Brazil: Lessons from Conventional Economics. Centennial Review 35(2):315-322.

O'Connor, James. 1994. Is Sustainable Capitalism Possible? Pp.152-175 in Is Capitalism Sustainable? Political Economy and the Politics of Ecology, edited by M. O'Connor. New York: The Guilford Press.

Roberts, J. Timmons. 1996. Predicting Participation in Environmental Treaties: A WorldSystem Analysis. Sociological Inquiry 66:38-57.

Roberts, J. Timmons and Peter E. Grimes. 1997. Carbon Intensity and Economic Development 1962-91: A Brief Exploration of the Environmental Kuznets Curve. World Development 25:191-198.

Rudel, Thomas K. 1989. Population, Development, and Tropical Deforestation: A CrossNational Study. Rural Sociology 54:327-338.

Sanderson, Stephen K. 1995. Social Transformations: A General Theory of Historical Development. Cambridge, MA: Blackwell.

Schaeffer, Robert K. 1997. Success and Impasse: The Environmental Movement in the United States and Around the World.? Presented at the Political Economy of the worldsystem XXI Conference, April, Santa Cruz, CA.

Smith, David A. 1994. Uneven Development and the Environment: Toward a WorldSystem Perspective. Humboldt Journal of Social Relations 20:151-175.

Walter, Ingo. 1982. Environmentally Induced Industrial Relocation to Developing Countries. In Environment and Trade: The Relation of International Trade and Environmental Policy, edited by S. Rubin and T. Graham. Totowa, NJ: Littlefield, Adams, and Co.

[Page 379]

Journal of World-Systems Research

\section{Notes}

1See Leonard (1988), Walter (1982), and Low and Yeats (1992) for tests of the pollutionhaven and industrial flight hypotheses that polluting industries have moved to the countries with the fewest environmental regulations.

2Rudel (1989) finds countries with large amounts of forested land their industrialization sustains high rates of deforestation, which is caused more by rural encroachment than by capital investment. He uses these findings to cast doubt upon a world-system analysis that 
would not take the amount of forested land to be as important as economic variables. Yet Kick et al. (1996) do take into account a country's amount of forest and still find that economic factors such as import and export dynamics have an effect on deforestation.

3GGrimes, Roberts, and Manale (1994) show that carbon dioxide produced through deforestation accounts for much of the variation around the inverted U-curve. Consequently, they identify several variables that help explain the differing levels deforestation-emissions both across world-system positions and within world-system positions. They find the greatest intensity in those countries in the lower periphery having large forest areas, and where pressure for land in the countryside is also high (1994:33). The findings seem to contradict Burns et al. (1994) and Kick et al. (1996), who locate the most intense deforestation in semiperipheral countries. Grimes et al use a measure of carbon dioxide from deforestation while the others use deforestation itself, but it is still not clear why the results should be so different.

4Chase-Dunn and Hall combine and extend the role accorded to ecological factors in circumscription (Carneiro 1970, 1981, 1987), resource stress (M. Harris 1977, 1979) and population pressure (Cohen 1977) theories. These theories account for the transition to agriculture and the development of hierarchical societies but not for the development of a world-system (see also Sanderson 1995).

[Page 380]

Joumal of World-Systems Research 